\title{
Measurement of casein in milk by Kjeldahl and sodium dodecyl sulfate-polyacrylamide gel electrophoresis
}

\author{
Larissa Di Marzo, ๑ Joice Pranata, $\odot$ and David M. Barbano* $\odot$ \\ Department of Food Science, Northeast Dairy Food Research Center, Cornell University, Ithaca, NY 14853
}

\section{ABSTRACT}

Our objectives were to determine if milk casein as a percentage of true protein $(\mathrm{CN} \% \mathrm{TP})$ estimated by sodium dodecyl sulfate-polyacrylamide gel electrophoresis (SDS-PAGE) is equivalent to $\mathrm{CN} \% \mathrm{TP}$ estimated by Kjeldahl, and to determine the proportion of casein $(\mathrm{CN})$, casein proteolysis products $(\mathrm{CNPP})$, and serum protein (SP) from milk true protein (TP) that goes into the Kjeldahl noncasein nitrogen (NCN) filtrate and the proportion that stays in the NCN precipitate using SDS-PAGE. Raw milk samples were collected from 16 mid-lactation Holstein cows twice a week for 2 wk. These milks were analyzed for Kjeldahl total nitrogen, nonprotein nitrogen, and NCN content in duplicate, and by SDS-PAGE. The CN\% TP determined by Kjeldahl was compared with the CN\% TP estimated by SDS-PAGE calculated in 2 ways: as a percentage of only intact caseins divided by TP and as a percentage of both intact caseins and CNPP divided by TP. Three milks varying in fat, lactose, $\mathrm{TP}, \mathrm{CN}$, and $\mathrm{SP}$ content were formulated. These milks were analyzed in duplicate for Kjeldahl total nitrogen, nonprotein nitrogen, and NCN content, and each of the NCN filtrate and NCN precipitate were analyzed in duplicate by SDSPAGE for relative quantity (\%) of CN, CNPP, and SP. We found that the estimate of CN\%TP by Kjeldahl was higher than the estimate of CN\%TP by SDS-PAGE that was calculated as only intact $\mathrm{CN}$ divided by the total of all protein bands. However, no difference was detected in the estimate of CN\%TP by Kjeldahl compared with CN\%TP by SDS-PAGE when CNPP were included as CN in the calculation of SDS-PAGE results. Based on SDS-PAGE results, we found that a majority $(89 \%)$ of the CNPP from the milk (approximately 10.13 out of $11.41 \% \mathrm{TP}$ ) were retained in the Kjeldahl NCN precipitate. Thus, CN\%TP measured by Kjeldahl underestimates the amount of proteolytic damage that

Received April 26, 2020.

Accepted January 29, 2021.

*Corresponding author: dmb37@cornell.edu has been done to $\mathrm{CN}$ in milk. It is important for the dairy industry to correctly and rapidly measure the extent of proteolytic damage to milk protein to correctly value milk from a product quality and yield point of view. A rapid and quantitative measure of proteolytic damage to milk protein is needed.

Key words: casein, casein proteolysis, Kjeldahl, sodium dodecyl sulfate-polyacrylamide gel electrophoresis

\section{INTRODUCTION}

In the US dairy market, the milk price calculation places strong economic emphasis on milk protein and fat (USDA, 2017). The true protein (TP) portion of milk (about $80-82 \% \mathrm{CN}$ ) has a significant effect on cheese yield (Margolies et al., 2017) and nutritional value (EAA and carrier of calcium) of fluid milk and dairy products (Fox et al., 2015). The 2 high-value macro components of milk are fat and protein, and the quality of the fat and protein are important for yield and sensory characteristics of dairy products and dairy ingredients. The quality of milk protein and fat can be degraded by the action of native milk enzymes and microbial spoilage organisms. Measurement of free fatty acids produced by the action of lipases in milk provides an index of milk fat quality, and measurement of peptides resulting from the action of proteases in milk provides an index of milk protein quality. There is a GLC reference method for measurement of free fatty acids in milk (IDF, 1991). Measurement of soluble nitrogen fractions in milk by the Kjeldahl method has been used to provide indices of proteolysis, but the Kjeldahl fractions are very nonspecific. Within the protein fraction of milk, there are 2 major groups of proteins: $\mathrm{CN}$ and whey proteins. In general, the $\mathrm{CN}$ are more susceptible to proteolysis than whey proteins.

The Kjeldahl method is the reference method for milk protein determination (AOAC International, 2000) based on the nitrogen content of milk and milk fractions. This method assumes that, on average, all milk proteins contain about $15.67 \%$ nitrogen, and then uses the resulting factor of 6.38 to convert total nitrogen $(\mathbf{T N})$ to total protein (Karman and van 
Boekel, 1986). The determination of nitrogen using the Kjeldahl method involves 3 steps: digestion to release nitrogen from protein, distillation to collect nitrogen in boric acid as ammonia, and titration to quantify the amount of nitrogen collected as a percentage by weight of the sample (Barbano et al., 1990; Lynch and Barbano, 1999).

In 1938, Samuel J. Rowland demonstrated that nitrogen in milk was distributed among several groups of proteins and that a portion of the nitrogen content in milk was not associated with proteins (Rowland,1938a,b). There are 3 primary nitrogen fractions of milk that are commonly measured with the Kjeldahl method today: TN, NPN, and noncasein nitrogen $(\mathbf{N C N})$, based on the Rowland milk nitrogen fraction scheme. The TP has been used as the basis for milk protein payment by the USDA federal milk markets since January 2000 . Using TP as the calibration basis for protein testing using mid-infrared analysis improved the accuracy of milk protein testing (Barbano and Lynch, 1992). The CN as percentage of TP (CN\% TP) has been used as an index of milk protein quality because CN\%TP decreases as proteolytic enzymes break down $\mathrm{CN}$. However, the Kjeldahl NCN method assumes that filtrate contains only the NCN components of milk. Karman and van Boekel (1986) suggested that during the Kjeldahl NCN analysis, a portion of the $\mathrm{CN}$ proteolysis products (CNPP) remain with the NCN precipitate, and another portion of the CNPP go into the NCN filtrate. Detailed method descriptions and collaborative studies of each of these methods have been published (Barbano et al., 1990, 1991; Lynch et al., 1998; Wojciechowski and Barbano, 2015).

The SDS-PAGE method is a secondary method that has been used to quantify the relative proportions of CN, CNPP, and serum proteins (SP) in milk (Verdi et al., 1987). In the SDS-PAGE method, a portion of milk is dissolved in a denaturing sample buffer solution that contains SDS anions and dithiothreitol. The SDS anions attach onto the protein, forming SDS-protein complexes that have similar and high negative charge density (Wrolstad et al., 2005). The milk dissolved in sample buffer is loaded on a polyacrylamide gel and an electric field is applied to the system. The milk proteins are separated based on their molecular weight. At the end of the run, the protein bands are stained with a dye, the gel is scanned, the bands are quantified, and the trace quantity (expressed as $\mathrm{mm} \times$ optical density; OD) of each protein band is given as result (Wrolstad et al., 2005).

In the literature, there is no specific information comparing the results given by Kjeldahl versus the results given by SDS-PAGE for estimation of $\mathrm{CN} \% \mathrm{TP}$ on the same milks. Our objectives were to determine if milk CN\%TP estimated by SDS-PAGE is equivalent to CN\%TP estimated by Kjeldahl, and to determine the proportion of CN, CNPP, and SP from milk TP that goes into the Kjeldahl NCN filtrate and the proportion that stays in the NCN precipitate using SDS-PAGE.

\section{MATERIALS AND METHODS}

\section{Experimental Design}

Raw milk from 16 mid-lactation Holstein cows were collected twice in each of $2 \mathrm{wk}$ for a total of 64 samples. All milks were cooled to $4^{\circ} \mathrm{C}$ immediately after collection, preserved with Microtab II (Advanced Instruments) bronopol preservative, and analyzed for $\mathrm{TN}$, NPN, and NCN content by Kjeldahl (in duplicate) and by SDS-PAGE. The CN\%TP given by Kjeldahl was calculated and compared with the CN\%TP estimated by SDS-PAGE calculated in 2 ways as follows: (1) using only intact $\mathrm{CN}$ bands divided by the total of all protein bands (i.e., CN + CNPP + SP) and (2) including the sum of intact CN and CNPP bands divided by the total of all protein bands.

Next, 3 milks varying in fat, lactose, TP, CN, and SP content were formulated as described by Kaylegian et al. (2006) and analyzed for Kjeldahl TN, NPN, and NCN content, in duplicate. During the Kjeldahl NCN sample preparation step, each NCN filtrate and NCN precipitate was collected and analyzed by SDS-PAGE, in duplicate. The relative quantity (\%) of CN, CNPP, and SP in each NCN filtrate and NCN precipitate (calculated as optical densitometer $\mathrm{mm} \times$ OD of each individual band or group of bands on the gel for a sample divided by the total $\mathrm{mm} \times \mathrm{OD}$ of all bands for that sample) was estimated, and the proportion (\%) of CN, CNPP, and SP from formulated milk that went into the Kjeldahl NCN filtrate and the proportion that went in the NCN precipitate was determined.

\section{Determination of CN\%TP by Kjeldahl Versus CN\%TP by SDS-PAGE}

Kjeldahl Analysis. Each of the 64 individual cow milks were analyzed in duplicate, following the procedures described by AOAC International as follows: TN (AOAC International, 2000; method 991.20), NPN (AOAC International, 2000; method 991.21), and NCN (AOAC International, 2000; method 998.05). The TP was calculated by subtracting NPN from TN and multiplying the result by the factor 6.38 . The $\mathrm{CN}$ was calculated by subtracting $\mathrm{NCN}$ from $\mathrm{TN}$ and multiplying the result by the factor 6.38; then, $\mathrm{CN} \% \mathrm{TP}$ was calculated. 
All milks were also subject to a screening analysis using mid-infrared milk spectrophotometric determination of milk components (Lactoscope FTA, Delta Instruments) and a flow cytometric SCC (Somasmart, Delta Instruments) to detect and exclude milk from any individual cow that was sick.

SDS-PAGE Analysis. The polyacrylamide gels used to determine the trace quantity $(\mathrm{mm} \times \mathrm{OD})$ of all protein bands (i.e., intact CN, CNPP, and SP) were made following the procedure described by Verdi et al. (1987) using the gel unit Protean II and the power unit 3000/300 from Bio-Rad (Bio-Rad Laboratories Inc.) gel electrophoresis system. The preparation of the samples for SDS-PAGE was done by diluting each milk with $0.9 \mathrm{~g}$ of a buffer that consisted of $10 \mathrm{mM}$ tris(hydroxymethyl) aminomethane (Tris)-HCl, 1.0\% SDS, $20 \%$ glycerol, $0.02 \%$ bromophenol blue tracking dye, and $45 \mathrm{~m} M$ dithiothreitol. The weight of milk used for the dilution was calculated based on Kjeldahl TP content of the milk sample to achieve a loading of approximately $28 \mu \mathrm{g}$ of TP loaded per slot. Each milk plus buffer mixture was placed in a sealed glass vial (Target DP Vials C4000-1W, National Scientific Co.), heated to $100^{\circ} \mathrm{C}$ using steam, held at $100^{\circ} \mathrm{C}$ for $3 \mathrm{~min}$, and stored frozen at $-80^{\circ} \mathrm{C}$. On the day of the SDSPAGE run, diluted milks were thawed by steam heating to $100^{\circ} \mathrm{C}$ for $3 \mathrm{~min}$, and then rapidly cooled in an ice-water mixture to about $25^{\circ} \mathrm{C}$. Each milk plus buffer mixture was loaded into a different well of the gel. The volume loaded was chosen to achieve a maximum peak OD in the range of 1.0 to 1.4 for the most intense protein band (i.e., $\alpha_{S}-\mathrm{CN}$ ) in the sample to avoid overloading and nonlinear response in quantitation. One raw milk sample was used as a marker in 1 lane of each gel for evaluation of loading consistency and comparison of resolution of the proteins from gel-to-gel. Three SDSPAGE runs were performed, each with 2 gels. All gels were scanned with USB GS 800 Densitometer (Bio-Rad Laboratories Inc.) and quantified using Quantity 1 1-D Analysis software (version 4.6.7, Bio-Rad Laboratories, Inc.).

For quantitative analysis, a center line for each lane on each gel was created during the scanning of the gel. The lines were adjusted individually to match the middle section of the bands in each lane. Next, each lane background was adjusted using the rolling disk method of subtraction to obtain a straight baseline for each lane. The detection of bands was done by setting the bracket width of the bands and then by adjusting each band in each lane by moving the brackets up or down based on visual observation. The trace quantity $(\mathrm{mm} \times \mathrm{OD})$ of the intact $\mathrm{CN}, \mathrm{CNPP}$, and SP bands, and the sum of all protein bands (i.e., CN + CNPP
+ SP), of the gel for each milk was calculated. The estimation of CN\%TP by SDS-PAGE was calculated in 2 ways as follows: (1) using only the intact $\mathrm{CN}$ bands divided by the total of all protein bands (i.e., CN\%TP) and (2) including the sum of intact $\mathrm{CN}$ plus CNPP bands divided by the total of all protein bands [CN $+\mathrm{CNPP} \% \mathrm{TP}$; i.e., $(\mathrm{CN}+\mathrm{CNPP}$ bands $) /$ all protein bands].

Statistical Analysis. Of the 64 milks, 1 was removed from the data set. Criteria for removal of outlier was based on the very high SCC (i.e., $3,330 \times 10^{3}$ cells/ $\mathrm{mL}$ ) of 1 cow for a specific week. A $t$-test was performed using JMP (JMP, Version Pro 13, SAS Institute Inc.) to determine if there was difference $(P<0.05)$ between the mean CN\%TP determined by Kjeldahl and the 2 estimations given by SDS-PAGE: (1) CN\%TP and (2) $\mathrm{CN}+\mathrm{CNPP} \% \mathrm{TP}$.

\section{Quantification of CN, CNPP, and SP (\%) in Kjeldahl NCN Filtrate and NCN Precipitate}

Selection of Milks. Three milks containing different fat, lactose, TP, CN, and SP content were formulated (Kaylegian et al., 2006) as part of the normal production of the modified milk calibration samples. Because of the ingredients and approach used to formulate these 3 modified milks (Kaylegian et al., 2006), it was expected that the protein content of the 3 milks would be different, but the CN\%TP determined by Kjeldahl analysis would be virtually the same. The 3 milks were analyzed in duplicate for total solids, lactose, and fat using forced-air oven drying (AOAC International, 2000; method 990.20; 33.2.44), enzymatic lactose (AOAC International, 2000; method 984.15; 33.2.67; Lynch et al., 2007), and ether extraction (AOAC International, 2000; method 989.05; 33.2.26), respectively.

Kjeldahl Analysis. Kjeldahl TN, NPN, and NCN methods were performed for each formulated milk, in duplicate, following the procedures described by the Association of Official Analytical Chemists International, as indicated above. For the Kjeldahl NCN analysis, the volume of acetic acid, sodium acetate, and water were adjusted according to the TP level, as recommended by Wojciechowski and Barbano (2015). The 6 Kjeldahl NCN filtrates (i.e., 3 milks in duplicate) and 6 NCN precipitates were collected to be analyzed by SDSPAGE.

$S D S-P A G E$ Analysis. Each of the 6 filtrates and the 6 precipitates resulting from Kjeldahl NCN analysis of the 3 milks, in duplicate, was collected and prepared for SDS-PAGE analysis, in duplicate. The preparation of each NCN filtrate for SDS-PAGE analysis started with the $\mathrm{pH}$ adjustment from 4.6 to 6.8 , using $1 \mathrm{~N}$ 
$\mathrm{NaOH}$ (course $\mathrm{pH}$ adjustment) or $0.1 \mathrm{~N} \mathrm{NaOH}$ (fine $\mathrm{pH}$ adjustment). Next, each filtrate was diluted in a buffer that consisted of $10 \mathrm{~m} M$ Tris-HCl, $1.0 \%$ SDS, $20 \%$ glycerol, $0.02 \%$ bromophenol blue tracking dye, and $45 \mathrm{mM}$ dithiothreitol. The weight of filtrate and buffer used for dilution was calculated based on TP content of each filtrate using the results given by Kjeldahl TN and NPN, assuming that all proteins in the NCN filtrate were SP. The target was to have filtrate + buffer mixtures with TP content of $0.3 \mu \mathrm{g} / \mu \mathrm{L}$. Each NCN filtrate + buffer mixture was placed in a sealed glass vial, heated to $100^{\circ} \mathrm{C}$ using steam, held at $100^{\circ} \mathrm{C}$ for $3 \mathrm{~min}$, and stored frozen at $-80^{\circ} \mathrm{C}$.

For the preparation of each NCN precipitate for SDSPAGE analysis, the precipitate was diluted into a buffer that consisted of $10 \mathrm{~m} M$ Tris-HCl, $1.0 \%$ SDS, $20 \%$ glycerol, $0.02 \%$ bromophenol blue tracking dye, and 45 $\mathrm{m} M$ dithiothreitol. The weight of NCN precipitate used for dilution was calculated based on TP content of each precipitate using the information given by Kjeldahl TN and NPN analysis of formulated milk, assuming that all proteins in the NCN precipitate were $\mathrm{CN}$ and CNPP. The target was to have precipitate + buffer mixtures with TP content of $8 \mu \mathrm{g} / \mu \mathrm{L}$. Each NCN precipitate + buffer mixture was placed in a sealed glass vial, heated to $100^{\circ} \mathrm{C}$ using steam, held at $100^{\circ} \mathrm{C}$ for $3 \mathrm{~min}$, and stored frozen at $-80^{\circ} \mathrm{C}$.

On the day of the SDS-PAGE run, diluted NCN filtrate and NCN precipitates were thawed by steam heating to $100^{\circ} \mathrm{C}$ for $3 \mathrm{~min}$, and then cooled to about $25^{\circ} \mathrm{C}$. Each sample was loaded into a well of the gel. For the NCN filtrate + buffer samples, the volume loaded was chosen to achieve a max OD in the range of 0.3 to 0.4 for the most intense protein band (i.e., $\beta-\mathrm{LG}$ ). For the NCN precipitate + buffer samples, the volume loaded was chosen to achieve a max OD in the range of 0.7 to 0.9 for the most intense protein band (i.e., $\alpha_{S^{-}} \mathrm{CN}$ ). It was assumed that the amount of Coomassie blue dying bond per unit of protein was the same for CN and SP. To verify this assumption, an SDS-PAGE analysis was performed using different concentrations of micellar CN concentrate and milk SP isolate $(5,10,15,20,25$, and $30 \mu \mathrm{g}$ of protein loaded per well; Nelson and Barbano, 2005). The dye binding rate (dye bound per unit weight of protein interacted with SDS) of Coomassie blue to CN was not significantly different than the binding rate to SP under the conditions used in SDS-PAGE analysis (data not shown). Raw milk was used as a marker on each gel for evaluation of loading consistency and resolution of the proteins from gel-to-gel. Two gels (i.e., front and back) were run and scanned with USB GS 800 Densitometer and quantified using Quantity 1 1-D Analysis software as described above. The relative quantity (\%) of IgG, BSA, lactoferrin (LFR), $\alpha_{S}-\mathrm{CN}$,
$\beta-\mathrm{CN}, \kappa-\mathrm{CN}, \beta-\mathrm{LG}, \alpha-\mathrm{LA}$, and CNPP for each NCN filtrate buffer mixture and each NCN precipitate buffer mixture was estimated. The relative quantities (\%) given by SDS-PAGE were used to calculate the proportion of CN, CNPP, and SP from milk that goes into the NCN filtrate and the proportion of CN, CNPP, and SP that stays in the NCN precipitate.

Statistical Analysis. A t-test was performed using JMP (JMP, Version Pro 13) to determine if the proportion of CN, CNPP, and SP (\%) from milk that goes into the Kjeldahl NCN filtrate was different $(P<0.05)$ than the proportion of CN, CNPP, and SP (\%) from milk that stays in the Kjeldahl NCN precipitate.

\section{RESULTS AND DISCUSSION}

\section{Determination of CN\%TP by Kjeldahl Versus CN\%TP by SDS-PAGE}

A typical SDS-PAGE gel separation of milk proteins is shown in Figure 1 for milk from 2 cows included in our study. The milk from cow 2 had much more proteolytic damage to $\mathrm{CN}$ with lower $(67.02 \%)$ intact $\mathrm{CN}$ (i.e., $\alpha-\mathrm{CN}+\beta-\mathrm{CN}+\kappa-\mathrm{CN})$ than for cow $1(76.34 \%)$. The CNPP identified as CNPP6 made a large contribution to the proteolysis products in the milk from cow 2 (Figure 1). The comparison of mean and standard deviation of CN\% TP estimated by Kjeldahl and CN\%TP estimated by SDS-PAGE is shown in Table 1. The mean CN\%TP estimated by Kjeldahl was higher $(P<0.05)$ than the mean CN\%TP estimated by SDSPAGE calculated using only intact $\mathrm{CN}$ divided by the total of all protein bands (Table 1). However, no difference was detected $(P>0.05)$ between Kjeldahl $\mathrm{CN} \% \mathrm{TP}($ mean $=81.05 \%)$ and SDS-PAGE CN\%TP $($ mean $=80.42 \%)$ calculated using the sum of intact $\mathrm{CN}$ and CNPP divided by the total of all protein bands (Table 1). The correlation of Kjeldahl CN\% TP with SDS-PAGE CN\%TP is shown in Figure 2. About $79 \%$ of the variability in mean Kjeldahl CN\% TP was explained by its relationship with SDS-PAGE CN + CNPP\%TP.

The fact that the Kjeldahl-estimated CN\% TP agreed better with SDS-PAGE measurement of CN\%TP when the CNPP were included in the calculation indicated that a substantial proportion of the CNPP may have precipitated with the intact $\mathrm{CN}$ in the Kjeldahl NCN method (Table 1). However, when there is proteolysis of $\mathrm{CN}$, it is not clear how much of the CNPP remain with the NCN precipitate and how much is soluble in the NCN filtrate. Therefore, the second part of the present study was conducted to estimate the proportion of CN proteolysis products that precipitate with intact $\mathrm{CN}$ in the Kjeldahl NCN method. 
(A)

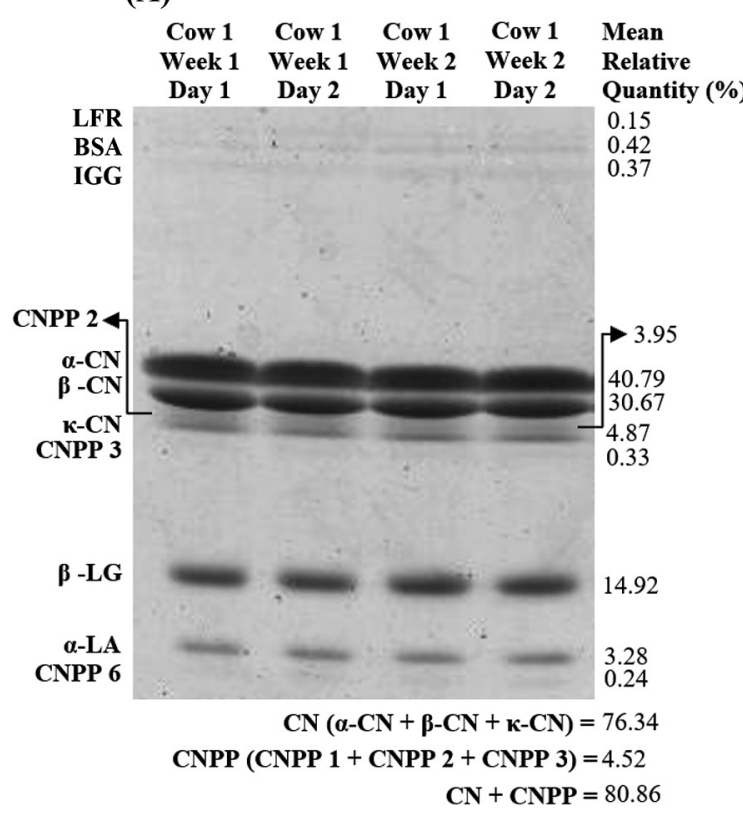

(B)

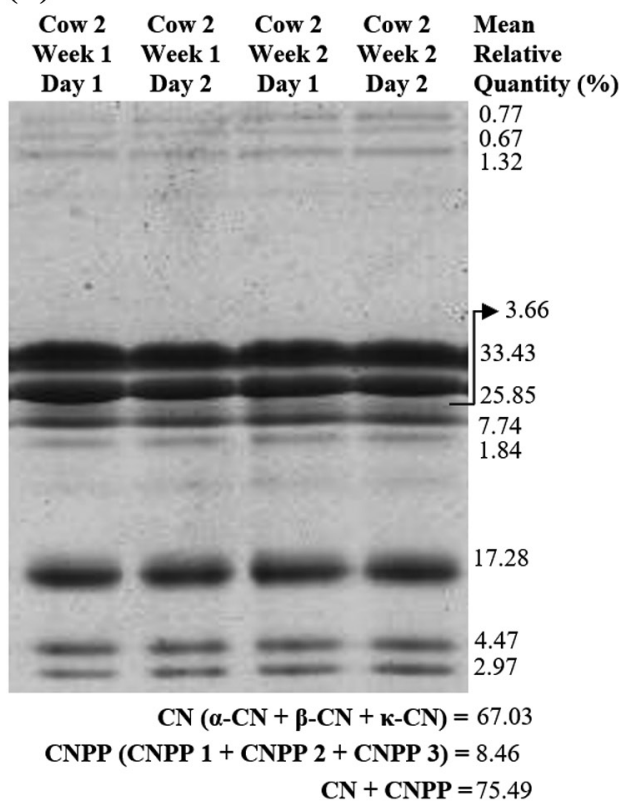

Figure 1. The SDS-PAGE analysis of milk from each of 2 mid-lactation Holstein cows collected twice in each of 2 wk. (A) Cow 1: milk with low casein proteolysis products (CNPP). (B) Cow 2: milk with high CNPP. Mean relative quantity (\%) of lactoferrin (LFR), BSA, IgG, $\alpha-C N$, $\beta$-CN, CNPP 2, $\kappa-\mathrm{CN}$, CNPP 3, $\beta$-LG, $\alpha$-LA, CNPP 6 , sum of intact CN (i.e., $\alpha$-CN $+\beta$-CN $+\kappa-C N$ ), sum of CNPP (i.e., CNPP $2+$ CNPP $3+\mathrm{CNPP} 6$ ), and CN+CNPP given by SDS-PAGE.

\section{Quantification of CN, CNPP, and SP (\%) in Kjeldahl NCN Filtrate and NCN Precipitate}

The chemical composition of the 3 formulated milks used for Kjeldahl NCN to produce the NCN filtrates and NCN precipitates is shown in Table 2. The composition of the 3 formulated milks were different, with varying levels of fat $(0.19,2.76$, and $5.76 \%)$, lactose (4.02, 4.57, and 5.11\%), and TP (4.26, 3.24, and 2.05). However, the 3 milks had about the same CN\%TP $(81.18,81.10,81.57)$.

We found that when using SDS-PAGE analysis of the Kjeldahl NCN filtrates and NCN precipitates, out of all intact milk $\mathrm{CN}, \kappa-\mathrm{CN}$ was the only one found in both NCN filtrate and precipitate (Table 3). Wojciechowski

Table 1. Mean $\mathrm{CN}$ as percentage of true protein $(\mathrm{CN} \% \mathrm{TP})$ and SD of milk samples estimated by Kjeldahl

\begin{tabular}{lcc}
\hline Method $^{1}$ & Mean CN\%TP (\%) & SD \\
\hline Kjeldahl & $81.05^{\mathrm{a}}$ & 2.35 \\
SDS-PAGE (intact CN only) & $75.80^{\mathrm{b}}$ & 4.37 \\
SDS-PAGE (CN + CNPP) & $80.42^{\mathrm{a}}$ & 2.99
\end{tabular}

\footnotetext{
${ }^{\mathrm{a}, \mathrm{b}}$ Means within a column not sharing a common superscript differ $(P$ $<0.05)$.

${ }^{1}$ The CN\%TP estimated with SDS-PAGE was calculated in 2 ways: (1) using only intact CN divided by the total of all protein bands, and (2) using the sum of $\mathrm{CN}$ and casein proteolysis products (CNPP) divided by the total of all protein bands.
}

and Barbano (2015) reported the presence of $\kappa-\mathrm{CN}$ in NCN filtrates with $\mathrm{pH}$ of 4.48 and 4.79. Furthermore, there were only $2 \mathrm{SP}$ present in the precipitate: $\beta-\mathrm{LG}$ and BSA. Because our formulated milks were pasteurized, some thermal denaturation of $\beta-L G$ occurred due to rupture of intramolecular disulfide bonds and subsequent formation of intermolecular disulfide bonds between $\beta$-LG and $\kappa$-CN (Zittle et al., 1962; Aurand et al., 1963). Hartman Jr. and Swanson (1965) also

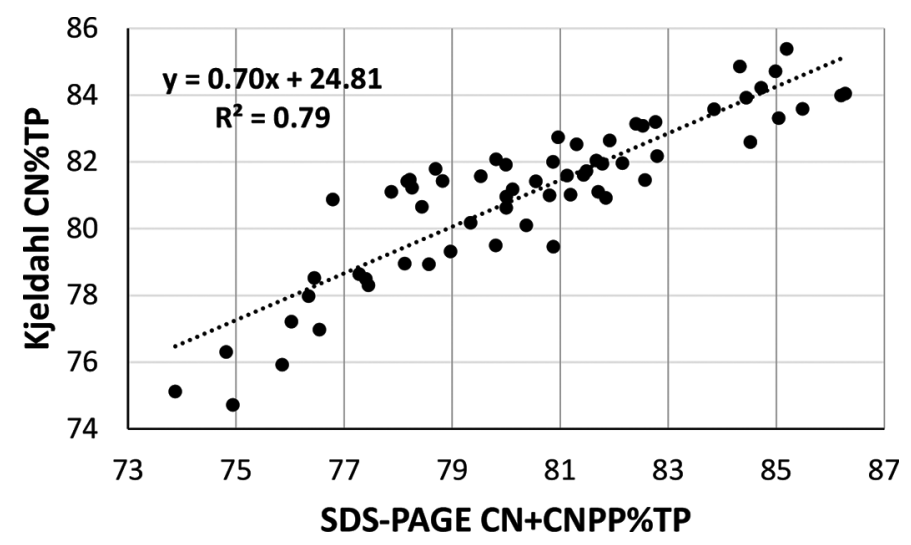

Figure 2. Kjeldahl CN as percentage of true protein (CN\%TP) plotted as a function of SDS-PAGE CN\% TP calculated using the sum of intact $\mathrm{CN}$ plus casein proteolysis products (CNPP) divided by the sum of all protein bands detected for 63 milks collected from 16 midlactation Holstein cows in 2 different weeks. 
Table 2. Chemical composition (\% by weight) of the 3 formulated milks used for quantification of CN, casein proteolysis products (CNPP), and serum proteins (SP) in Kjeldahl noncasein nitrogen (NCN) filtrate and NCN precipitate

\begin{tabular}{|c|c|c|c|c|c|c|c|c|c|c|c|}
\hline \multirow[b]{2}{*}{ Milk } & \multicolumn{11}{|c|}{ Composition $^{1}$} \\
\hline & TS & Lactose & Fat & $\mathrm{TN}$ & $\mathrm{NPN}$ & $\mathrm{NCN}$ & $\mathrm{TP}$ & $\mathrm{CN}$ & SP & $\mathrm{CN} \% \mathrm{TP}$ & $\mathrm{SP} \% \mathrm{TP}$ \\
\hline 2 & 11.691 & 4.573 & 2.764 & 3.428 & 0.185 & 0.798 & 3.243 & 2.630 & 0.613 & 81.098 & 18.902 \\
\hline 3 & 13.963 & 5.113 & 5.759 & 2.228 & 0.182 & 0.559 & 2.046 & 1.669 & 0.377 & 81.574 & 18.426 \\
\hline
\end{tabular}

${ }^{1} \mathrm{TN}=$ total nitrogen $\times 6.38 ; \mathrm{NPN}=$ nonprotein nitrogen $\times 6.38 ; \mathrm{NCN}=$ noncasein nitrogen $\times 6.38 ; \mathrm{TP}=$ true protein $(\mathrm{TN}-\mathrm{NPN}) ; \mathrm{CN}=$ $\mathrm{CN}(\mathrm{TN}-\mathrm{NCN}) ; \mathrm{SP}=$ serum protein $(\mathrm{TP}-\mathrm{CN}) ; \mathrm{CN} \% \mathrm{TP}=\mathrm{CN}$ as a percentage of $\mathrm{TP} ; \mathrm{SP} \% \mathrm{TP}=\mathrm{SP}$ as a percentage of $\mathrm{TP}$.

found that a stable complex was formed when $\beta$-LG was heated with $\kappa$-CN. However, a stable complex was not formed when BSA was heated with $\kappa-\mathrm{CN}$. The author suggests that heated BSA precipitates with $\mathrm{CN}$ at $\mathrm{pH} 4.7$ and does not interact with $\mathrm{CN}$ during heating. The IgG and LFR were present in the filtrate but not in the precipitate (Table 3 ), and this might be because the isoelectric point of these proteins are higher than 4.6 , which is the isoelectric point of CN (Josephson et al., 1972; Liang et al., 2011).

To facilitate the interpretation of our SDS-PAGE results in comparison to Kjeldahl data, the proteins were divided in 3 main groups: intact $\mathrm{CN}$ (i.e., $\alpha-\mathrm{CN}$ $+\beta-\mathrm{CN}+\kappa-\mathrm{CN}$ ), CNPP, and $\mathrm{SP}$ (i.e., $\mathrm{IgG}+\mathrm{BSA}+$ LFR $+\beta-\mathrm{LG}+\alpha$-LA). These are expressed as mean relative quantity (\%), shown in Table 4 . Using the SDSPAGE results from Table 4, we estimated the mean relative quantity (\%) of the 3 main proteins in milk used for the Kjeldahl NCN analysis. We found (Table 5) that $69.74 \%$ of the milk $\mathrm{TP}$ was intact $\mathrm{CN}, 11.41 \%$ of milk TP was CNPP, and $18.85 \%$ of milk TP was SP.

We used the Kjeldahl TN, NPN, and NCN results in combination with the SDS-PAGE results to calculate the percent of intact CN, CNPP, and SP from milk that goes into the Kjeldahl NCN filtrate and Kjeldahl NCN precipitate (Table 6). About $81.28 \%$ of milk TP was $\mathrm{CN}$, based on Kjeldahl results. However, we found that out of $81.28 \%$, only $69.10 \%$ was intact $\mathrm{CN}$, and $10.13 \%$ was CNPP (Table 6) when using SDS-PAGE. It can be seen from the scan of the SDS-PAGE gel (Figure 3) that the CNPP 6 band made the largest contribution in the CNPP percent value estimated for the NCN precipitate. Trieu-Cuot and Gripon (1981) reported that this band consists of $\gamma_{2}$ - CN and $\gamma_{3}$-CN. Because of their high hydrophobicity, these 2 peptides precipitate with $\mathrm{CN}$ in the Kjeldahl NCN sample preparation method. Based on SDS-PAGE results, $11.41 \%$ of the milk TP was CNPP (Table 5), and most of these CNPP (10.13\% of milk TP) went into the NCN precipitate, and only a small fraction (1.28\% of milk TP) remained in the NCN filtrate (Table 6). Therefore, the portion of CNPP from formulated milk that stayed with the NCN precipitate during Kjeldahl NCN analysis was significantly different $(P<0.05)$ than the CNPP that went into the filtrate. The Kjeldahl CN\%TP metric for a milk sample underestimates the amount of enzymatic damage that has happened to $\mathrm{CN}$ because most of the $\mathrm{CN}$ proteolysis products of $\mathrm{CN}$ are retained in the NCN precipitate and counted as CN. The functionality, product yield, and flavor implications of this are different for different dairy products.

Although a small amount of intact $\mathrm{CN}$ remained in the NCN filtrate, a relatively larger amount of CNPP and SP went into the NCN precipitate, increasing the Kjeldahl CN\%TP value (Table 6). The net effect was an overestimation of CN\% TP by Kjeldahl when CN

Table 3. Mean relative quantity (\%) of IgG, BSA, lactoferrin (LFR), $\alpha-\mathrm{CN}, \beta-\mathrm{CN}, \kappa-\mathrm{CN}, \beta-\mathrm{LG}, \alpha-\mathrm{LA}$, and casein proteolysis products (CNPP) in Kjeldahl noncasein nitrogen $(\mathrm{NCN})$ filtrate and precipitate determined with SDS-PAGE ${ }^{1}$

\begin{tabular}{|c|c|c|c|c|c|c|c|c|c|c|}
\hline Kjeldahl NCN & $\operatorname{IgG}$ & BSA & LFR & $\alpha-\mathrm{CN}$ & $\beta-\mathrm{CN}$ & $\kappa-\mathrm{CN}$ & $\beta-\mathrm{LG}$ & $\alpha-\mathrm{LA}$ & CNPP & Total \\
\hline Filtrate 2 & 1.11 & ND & 2.44 & ND & ND & 3.08 & 67.73 & 19.13 & 6.52 & 100 \\
\hline Filtrate 3 & 1.59 & ND & 2.80 & ND & ND & 2.94 & 66.79 & 19.28 & 6.60 & 100 \\
\hline SD & 0.29 & ND & 0.43 & ND & ND & 0.92 & 1.32 & 1.07 & 1.13 & 0 \\
\hline Precipitate 1 & ND & 0.92 & ND & 43.57 & 32.88 & 8.43 & 1.14 & ND & 13.07 & 100 \\
\hline Precipitate 2 & ND & 1.26 & ND & 43.89 & 32.57 & 8.57 & 1.19 & ND & 12.53 & 100 \\
\hline
\end{tabular}

${ }_{\mathrm{a}, \mathrm{b}}$ Means within a column not sharing a common superscript differ $(P<0.05)$.

${ }^{1} \mathrm{ND}=$ not detected. 
Table 4. Mean relative quantity (\%) of intact CN, casein proteolysis products (CNPP), and serum proteins $(\mathrm{SP})$ in the Kjeldahl noncasein nitrogen $(\mathrm{NCN})$ filtrate and in the precipitate determined with SDS-PAGE

\begin{tabular}{|c|c|c|c|c|}
\hline Kjeldahl NCN & Intact $\mathrm{CN}$ & CNPP & $\mathrm{SP}$ & $\mathrm{CN}+\mathrm{CNPP}+\mathrm{SP}$ \\
\hline Filtrate 1 & 4.21 & 7.45 & 88.34 & 100 \\
\hline Filtrate 2 & 3.08 & 6.52 & 90.40 & 100 \\
\hline Filtrate 3 & 2.94 & 6.60 & 90.47 & 100 \\
\hline Mean & $3.41^{\mathrm{a}}$ & $6.86^{\mathrm{b}}$ & $89.74^{\mathrm{b}}$ & 100 \\
\hline $\mathrm{SD}$ & 0.92 & 1.13 & 1.62 & 0 \\
\hline Precipitate 1 & 84.87 & 13.07 & 2.06 & 100 \\
\hline Precipitate 2 & 85.03 & 12.53 & 2.45 & 100 \\
\hline Precipitate 3 & 85.14 & 11.79 & 3.08 & 100 \\
\hline Mean & $85.01^{\mathrm{b}}$ & $12.46^{\mathrm{a}}$ & $2.53^{\mathrm{a}}$ & 100 \\
\hline SD & 1.77 & 1.76 & 0.54 & 0 \\
\hline
\end{tabular}

$\overline{\mathrm{a}, \mathrm{b}}$ Means in the same column not sharing a common superscript differ $(P<0.05)$.

Table 5. Mean and SD of intact CN, casein proteolysis products (CNPP), serum protein (SP), and sum of intact CN, CNPP, and SP (intact CN + CNPP + SP) in formulated milks, expressed as percent of true protein (TP) in milk and estimated by SDS-PAGE; and mean and SD of Kjeldahl total protein (TP) nitrogen (\%) in 3 formulated milks

\begin{tabular}{lcccccc}
\hline \multirow{2}{*}{$\begin{array}{l}\text { Kjeldahl } \\
\text { noncasein } \\
\text { nitrogen (NCN) }\end{array}$} & \multicolumn{3}{c}{ SDS-PAGE (\% of TP in milk) } & & Kjeldahl \\
\cline { 2 - 4 } \cline { 6 - 6 } & Intact $\mathrm{CN}^{1}$ & $\mathrm{CNPP}^{2}$ & $\mathrm{SP}^{3}$ & $\mathrm{CN}+\mathrm{CNPP}+\mathrm{SP}$ & & (\% of TP nitrogen) \\
\hline Milk 1 & 69.69 & 12.01 & 18.30 & 100 & 100 \\
Milk 2 & 69.54 & 11.39 & 19.07 & 100 & 100 \\
Milk 3 & 69.99 & 10.83 & 19.18 & 100 & 100 \\
Mean & 69.74 & 11.41 & 18.85 & 100 & 100 \\
SD & 1.54 & 1.41 & 0.57 & 0 & 0 \\
\hline
\end{tabular}

${ }^{1}$ Intact $\mathrm{CN}=$ intact $\mathrm{CN}$ in the $\mathrm{NCN}$ filtrate + intact $\mathrm{CN}$ in the NCN precipitate.

${ }^{2} \mathrm{CNPP}=\mathrm{CNPP}$ in the NCN filtrate $+\mathrm{CNPP}$ in the NCN precipitate.

${ }^{3} \mathrm{SP}=\mathrm{SP}$ in the NCN filtrate $+\mathrm{SP}$ in the NCN precipitate.

Table 6. Mean and SD of CN, casein proteolysis products (CNPP), serum protein (SP), and sum of CN, $\mathrm{CNPP}$, and $\mathrm{SP}(\mathrm{CN}+\mathrm{CNPP}+\mathrm{SP})$ estimated by SDS-PAGE in the Kjeldahl noncasein nitrogen (NCN) filtrates and NCN precipitates, expressed as percent of true protein (TP) in milk; and mean and SD of Kjeldahl TP nitrogen (\%) in the Kjeldahl NCN filtrates and NCN precipitates

\begin{tabular}{lcccccc}
\hline & \multicolumn{3}{c}{ SDS-PAGE (\% of TP in milk) } & & Kjeldahl \\
\cline { 2 - 5 } \cline { 6 - 7 } Kjeldahl NCN & Intact CN & CNPP & SP & CN + CNPP + SP & & (\% of TP nitrogen) \\
\hline Filtrate 1 & 0.79 & 1.40 & 16.63 & 18.83 & 18.83 \\
Filtrate 2 & 0.58 & 1.23 & 17.09 & 18.90 & 18.90 \\
Filtrate 3 & 0.54 & 1.22 & 16.67 & 18.43 & 18.43 \\
Mean & $0.64^{\mathrm{b}}$ & $1.28^{\mathrm{b}}$ & $16.80^{\mathrm{a}}$ & $18.72^{\mathrm{b}}$ & 0.22 & 0.22 \\
SD & 0.18 & 0.21 & 0.32 & 81.18 & 81.18 \\
Precipitate 1 & 68.90 & 10.61 & 1.67 & 81.10 & 81.10 \\
Precipitate 2 & 68.96 & 10.16 & 1.99 & 81.57 & 81.57 \\
Precipitate 3 & 69.45 & 9.62 & 2.51 & $81.28^{\mathrm{a}}$ & \\
Mean & $69.10^{\mathrm{a}}$ & $10.13^{\mathrm{a}}$ & $2.06^{\mathrm{b}}$ & 0.22 & 0.22 \\
SD & 1.46 & 1.43 & 0.45 & & \\
\hline
\end{tabular}

$\overline{a, b}$ Means in the same column not sharing a common superscript differ $(P<0.05)$. 


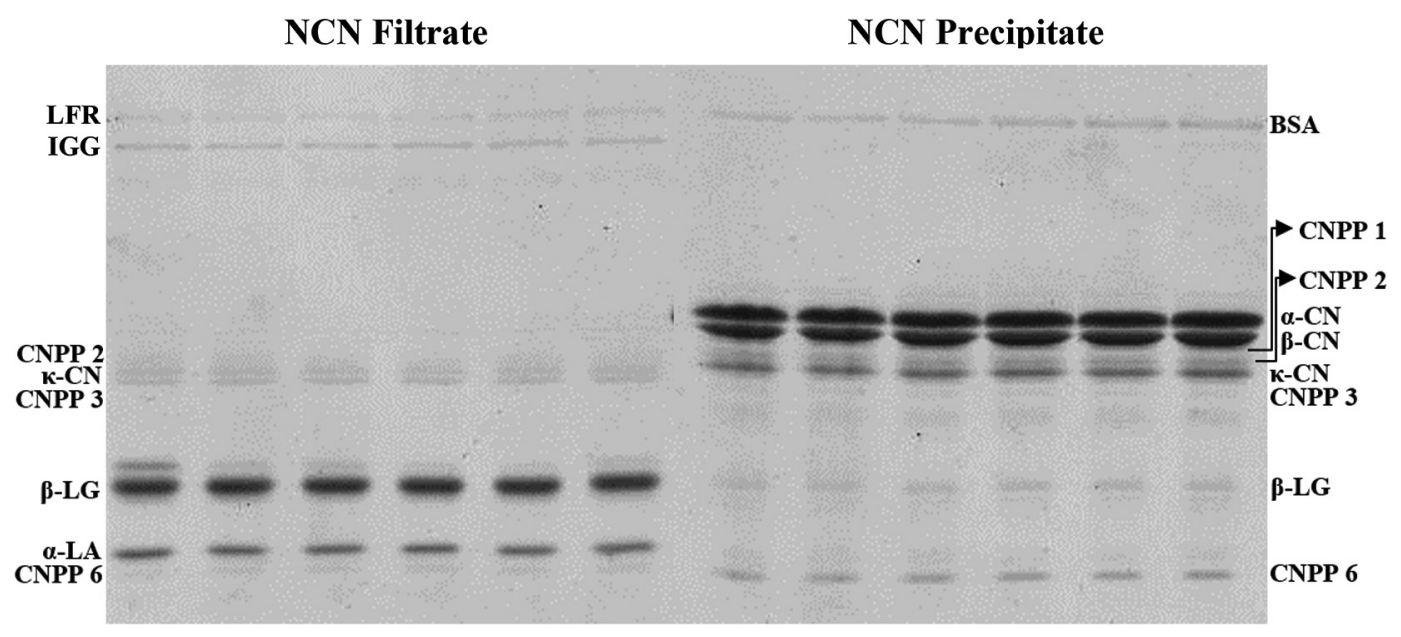

Figure 3. The SDS-PAGE gel loaded using 3 Kjeldahl noncasein nitrogen (NCN) filtrates and 3 Kjeldahl NCN precipitates, in duplicate. From left to right: filtrate 1 (R1), filtrate 1 (R2), filtrate 2 (R1), filtrate 2 (R2), filtrate 3 (R1), filtrate 3 (R2), precipitate 1 (R1), precipitate 1 $(\mathrm{R} 2)$, precipitate $2(\mathrm{R} 1)$, precipitate $2(\mathrm{R} 2)$, precipitate $3(\mathrm{R} 1)$, and precipitate $3(\mathrm{R} 2)$, where $\mathrm{R}=$ replicate. $\mathrm{LFR}=$ lactoferrin; $\mathrm{CNPP}=\mathrm{CN}$ proteolysis products.

was defined as only intact CN in SDS-PAGE without the inclusion of CNPP. A rapid method to measure CNPP in milk is needed to reflect the amount of proteolysis of CN and the quality of milk protein. This may be achieved by development of a partial least squares model to quantify CNPP using a mid-infrared analysis.

\section{CONCLUSIONS}

We compared the Kjeldahl estimate of CN\%TP with the SDS-PAGE estimate of CN\%TP and determined the proportion of CN, CNPP, and SP in the Kjeldahl NCN filtrate and precipitate. We found that the estimate of CN\%TP by Kjeldahl was higher than the estimate of CN\%TP by SDS-PAGE calculated as intact CN bands divided by the total of all protein bands. However, no significant difference was detected in the estimate of CN\%TP between Kjeldahl and SDS-PAGE when the calculation of CN\%TP by SDS-PAGE included intact $\mathrm{CN}+\mathrm{CNPP}$. Thus, the classical Kjeldahl NCN analysis underestimated the amount of proteolytic enzyme damage that happens to $\mathrm{CN}$ because casein proteolysis products were retained in the $\mathrm{pH} 4.6$ precipitate. A rapid method to measure the extent of proteolysis in milk would be very useful for dairy herd management and milk quality improvement.

\section{ACKNOWLEDGMENTS}

The authors thank the Miner Institute (Chazy, NY) for their collaboration by providing individual cow milks for use in the study. The authors thank the Northeast Dairy Foods Research Center (Ithaca, NY) for support of this research. The technical assistance of Chassidy Coon, Michelle Billota, and Sara Bova of Cornell University (Ithaca, NY) was greatly appreciated. Use of names, names of ingredients, and identification of specific models of equipment is for scientific clarity and does not constitute any endorsement of product by authors or Cornell University. The authors have not stated any conflicts of interest.

\section{REFERENCES}

AOAC International. 2000. Official Methods of Analysis. 17th ed. AOAC International.

Aurand, L. W., J. W. Brown, and J. G. Lecce. 1963. Effect of heat on the proteins of milk as revealed by gel and immunoelectrophoresis. J. Dairy Sci. 46:1177-1182. https://doi.org/10.3168/jds.S0022 $-0302(63) 89241-3$.

Barbano, D. M., J. L. Clark, C. E. Dunham, and J. R. Flemin. 1990. Kjeldahl method for determination of total nitrogen content of milk: Collaborative study. J. AOAC Int. 73:849-859. https://doi .org/10.1093/jaoac/73.6.849.

Barbano, D. M., and J. M. Lynch. 1992. Crude and protein nitrogen bases for protein measurement and their impact on current testing accuracy. J. Dairy Sci. 75:3210-3217. https://doi.org/10.3168/jds .S0022-0302(92)78086-2.

Barbano, D. M., J. M. Lynch, and J. R. Fleming. 1991. Direct and indirect determination of true protein content of milk by Kjeldahl analysis: Collaborative study. J. AOAC Int. 74:281-288. https:// doi.org/10.1093/jaoac/74.2.281.

Fox, P. F., T. Uniacke-Lowe, P. L. H. McSweeney, and J. A. O'Mahony. 2015. Biologically Active Compounds in Milk: Bioactive Milk Proteins. Page 424 in Dairy Chemistry and Biochemistry. Springer.

Hartman, G. H. Jr., and A. M. Swanson. 1965. Changes in mixtures of whey protein and k-casein due to heat treatments. J. Dairy Sci. 48:1161-1167. https://doi.org/10.3168/jds.S0022-0302(65)88420 -X.

IDF. 1991. Determination of free fatty acids in milk and milk products. International Dairy Federation.

Josephson, R. V., E. M. Mikolajick, and D. P. Sinha. 1972. Gel isoelectric focusing of selected bovine immunoglobulins. J. Dairy Sci. $55: 1508-1510$. 
Karman, A. H., and M. A. J. S. van Boekel. 1986. Evaluation of the Kjeldahl factor for conversion of the nitrogen content of milk and milk products to protein content. Neth. Milk Dairy J. 40:315-336.

Kaylegian, K. E., G. E. Houghton, J. M. Lynch, J. R. Fleming, and D. M. Barbano. 2006. Calibration of infrared milk analyzers: modified milk versus producer milk. J. Dairy Sci. 89:2817-2832. https://doi .org/10.3168/jds.S0022-0302(06)72555-3.

Liang, Y., X. Wang, M. Wu, and W. Zhu. 2011. Simultaneous isolation of lactoferrin and lactoperoxidase from bovine colostrum by SPEC 70 SLS cation exchange resin. Int. J. Environ. Res. Public Health 8:3764-3776. https://doi.org/10.3390/ijerph8093764.

Lynch, J. M., and D. M. Barbano. 1999. Kjeldahl nitrogen analysis as a reference method for protein determination in dairy products. J. AOAC Int. 82:1389-1398. https://doi.org/10.1093/jaoac/82.6 .1389 .

Lynch, J. M., D. M. Barbano, and J. R. Fleming. 2007. Determination of the lactose content of fluid milk by spectrophotometric enzymatic analysis using weight additions and path length adjustment: Collaborative study. J. AOAC Int. 90:196-216.

Lynch, J. M., D. M. Barbano, and J. R. Fleming. 1998. Indirect and direct determination of the casein content of milk by Kjeldahl nitrogen analysis: collaborative study. J. AOAC Int. 81:763-774. https://doi.org/10.1093/jaoac/81.4.763.

Margolies, B., M. C. Adams, J. Pranata, K. Gondoutomo, and D. M. Barbano. 2017. Effect of uncertainty in composition and weight measures in control of cheese yield and fat loss in large cheese factories. J. Dairy Sci. 100:6822-6852. https://doi.org/10.3168/jds .2016-12295.

Nelson, B. K., and D. M. Barbano. 2005. A microfiltration process to maximize removal of serum proteins from skim milk before cheese making. J. Dairy Sci. 88:1891-1900. https://doi.org/10.3168/jds .S0022-0302(05)72865-4.

Rowland, S. J. 1938a. The precipitation of the proteins in milk: I. Casein II. Total proteins III. Globulin IV. Albumin and pro- teosepeptone. J. Dairy Res. 9:30-41. https://doi.org/10.1017/ S0022029900002284.

Rowland, S. J. 1938b. The determination of the nitrogen distribution in milk. J. Dairy Res. 9:42-46. https://doi.org/10.1017/ S0022029900002296.

Trieu-Cuot, P., and J. Gripon. 1981. Electrofocusing and two-dimensional electrophoresis of bovine caseins. J. Dairy Res. 48:303-310. https://doi.org/10.1017/S0022029900021725.

USDA. 2017. Announcement of advanced prices and pricing factors. Accessed Apr. 27, 2017. https://www.ams.usda.gov/mnreports/ dymadvancedprices.pdf.

Verdi, R. J., D. M. Barbano, M. E. Dellavalle, and G. F. Senyk. 1987. Variability in true protein, casein, nonprotein nitrogen, and proteolysis in high and low somatic cell count milks. J. Dairy Sci. 70:230-242. https://doi.org/10.3168/jds.S0022-0302(87)80002-4.

Wojciechowski, K. L., and D. M. Barbano. 2015. Modification of the Kjeldahl noncasein nitrogen method to include bovine milk concentrates and milks from other species. J. Dairy Sci. 98:7510-7526. https://doi.org/10.3168/jds.2015-9580.

Wrolstad, R. E., T. E. Acree, E. A. Decker, M. H. Penner, D. S. Reid, S. J. Schwartz, C. F. Shoemaker, D. Smith, and P. Sporns. 2005. Characterization of proteins. Pages 155-265 in Handbook of Food Analytical Chemistry. John Wiley \& Sons Inc.

Zittle, C. A., M. P. Thompson, J. H. Custer, and J. Cerbulis. 1962. $\kappa$-casein - $\beta$-LG interaction in solution when heated. J. Dairy Sci. 45:807-810. https://doi.org/10.3168/jds.S0022-0302(62)89501-0.

\section{ORCIDS}

Larissa Di Marzo @ https://orcid.org/0000-0002-4857-2513

Joice Pranata @ https://orcid.org/0000-0002-9638-0575

David M. Barbano @ https://orcid.org/0000-0002-0206-7028 